ISSN 2411-4758 (Print) 2518-1602 (Online)

Native word in ethnocultural dimension, Drohobych, Posvit, 2021, pp. 227-230.

DOI: https://doi.org/10.24919/2411-4758.2021.213394

УДК 821.161.2.09(092)+821.162.1.09(092)

THE WORD ABOUT PERSONAL MYTH OF IVAN FRANKO, ANDZHEJ KTSIUK AND BRUNO SHULTS (review of a monograph: Durkalevych, V.V. (2015). In Searching for Narrative Identity: Personal Myth in the works of Ivan Franko, Andzhej Ktsiuk and Bruno Shults. Drohobych: Kolo)

\title{
Halina SABAT
}

Doctor of Philology, Professor of the Department of Romance Philology and Comparative Studies, Ivan Franko Drohobych State Pedagogical University (Ukraine, Drohobych).

ORCID: $\underline{\text { http://orcid.org/0000-0002-5057-58-14 }}$

Research ID: AAD-19-51-2019 http://www.researcherid.com/rid/AAD-19$\underline{51-2019}$

Статтю подано до редколегіi/The article is submitted to the editorial board: 05.10 .2020 .

Статтю опубліковано/The article is published: 22.02.2021.

\section{СЛОВО ПРО ІНДИВІДУАЛЬНИЙ МІФ ІВАНА ФРАНКА,} АНДЖЕЯ ХЦЮКА І БРУНО ШУЛЬЦА (рецензія на монографію: Дуркалевич, В.В. (2015). У пошуках наративної ідентичності : індивідуальний міф у творах Івана Франка, Анджея Хиююка і Бруно Шульца. Дрогобич : Коло)

\section{Галина САБАТ}

доктор філологічних наук, професор кафедри романської філології та компаративістики, Дрогобицький державний педагогічний університет імені Івана Франка (Україна, Дрогобич)

У рецензї наголошено, щуо світ Франкового слова - невичерпне джерело для розмаїтих інтерпретаційних наближень і щзо важливу роль у процесі актуалізації інтерпретаційного потенціалу Франкової спадщини відіграє ї̈ багатоаспектна контекстуалізація. Показано, щуо В. Дуркалевич вдалося знайти власний інтерпретаційний підхід до творів Івана Франка, Бруно Шульциа й Анджея Хиююка: вибудувано оригінальний інтердисииплінарний дискурс, у якому головну роль відведено таким поняттям, як наративна ідентичність, індивідуальний міф 
і культурна пам'ять, щчо допомагають виявити й проаналізувати спільні для творчості усіх трьох авторів механізми сенсотворення. Стверджено, щуо до проблеми символічної біографії, як і до концепцій індивідуального міфу, зверталися Г. Грабович, О. Забужко, Т. Мейзерська, Я. Полімук, Л. Демидюк, Т. Жовновська; опрацьовано також поняття символічної чи культурної біографії у проекиії на творчий доробок Івана Франка; досліджено твори Бруно Шульйа й Анджея Хиююка, зокрема й у компаративному аспекті.

У рецензї запрезентовано структуру монографії та основний зміст ї̈ розділів. Показано, щуо у вступі обтрунтовано потребу досліджень такого типу, зазначено їхне теоретичне підгрунтя й загальнотеоретичну значущість, пов 'язану з певними робочими формулами, які перетворюють теорію на реально чинний інструмент рецепції. Засвідчено, що всі розділи рецензованої монографіі - изе багатоаспектне інтерпретаційне наближення до творчості Івана Франка, Бруно Шульца та Анджея Хиюка. Дослідния акиентує увагу на специфіиі конституювання індивідуального міфу в їхніх текстах $і$ доводить, щчо вагому роль у їх (міфів) прочитанні відіграють філософія слова і літературна герменевтика, авторська рефлексія й саморефлексія у вигляді виразно артикульованого метадискурсу. Наголошено, щчо розрізнені на перший погляд розділи праці цілісно гармонують. Констатовано, щуо рецензована праця поглиблює проблему індивідуального міфу передусім із філософських позицій і підтверджено слушність обстоюваної в ній думки, щуо хронотопний аналіз має межу застосування й наслідки його застосування необхідно перевіряти та поглиблювати іншими методиками.

First of all I note the encouraging fact that Laboratory of Ivan Franko and Slavic Studies of Drohobych Ivan Franko State Pedagogical University constantly directs young scientists to study Ivan Franko's life and work as a social and cultural phenomenon in his universality. The new facts are introduced in scientific use, the literary, philosophical and historiosophical heritage of great writer is promoted in a new way. This fact is confirmed by a number of issues «Ivan Franko's Studies» and specifically the reviewed monograph of Victoria Durkalevych - the researcher of Ivan Franko's Laboratory.

Ivan Franko's creative heritage is as unique phenomenon as wholeUkrainian one. We can't speak about Andzhej Ktsiuk and Bruno Shults in the same way despite the fact that all of them deal with the Ukrainian topos. It is evidenced by Ivan Franko's small prose, specifically by such autobiographical texts as «Small Myron», «Mykytych's oak», «My crime», «Hryt's School Lesson», «The Pencil», «Father humorist» and others. They contain extremely intellectualized spirit of native land, escaped from folklore «decanters» and celebrates the freedom in a new way reasonably and uninhibited.

Viktoriya Durkalevych's monograph «In Searching for Narrative Identity: Personal Myth in the works of Ivan Franko, Andzhej Ktsiuk and Bruno 
Shults» - doesn't forget about this nerve of Ivan Franko's artistic thinking, especially in the second chapter.

The world of Ivan Franko's word still remains as inexhaustible source for various interpretational approximations. Properly selected theories and concepts allow to open new facets of Franko as an artist. The multifaceted contextualization plays an important role in the process of updating interpretative potential of Franko's heritage.

It is specifically spoken about the possibility of chronotope research promlems, more precisely - about Drohobych text and its correlation in the works of Ivan Franko and other artists, for whom Drohobych plays the role of significant topos. The author however goes beyond this problematic and offers to research the works of Ivan Franko, Andzhej Ktsiuk and Bruno Shults through the prism of personal myth.

Many native scholars have been studied the problem of symbolic biography as well as the concept of personal myth. Regarding to this we can name some of them: "The Poet as a Mythmaker: A Study of Symbolic Meaning in Taras Shevchenko's works» by George Grabowicz, «Shevchenko's Myth of Ukraine» by Oksana Zabuzhko, «Problems of Individual Mythologies: Shevchenko's Mythmaking» by Tetyana Meyzerska, "The Mythological Horizon of the Ukrainian Modernism» by Yaroslav Polishchuk, «Mythological paradigm of Nickolay Vorobyov's poetries» by Demydiuk Liliya, «The Discourse on Oneirical and Mythological Aspects of Valeriy Shevchuk's Prose» by Tetyana Zhovnovskaya.

The concepts of symbolic and cultural biography in the projection on Ivan Franko's works are also analyzed. In this context it is necessary to mention such important researches as: «Texts and Masks» by George Grabovych and «Franko is/not the 'Stonecutter» by Tamara Hundorova. The works of Andzhej Ktsiuk and Bruno Shults have found their researchers. Among them are « Bruno Shults the Great Inhabitant of Drohobych» by Roman Mnych, in which «comparative parallels» of Bruno Shults and Ivan Franko's works are represented, and monograph «Ethnocultural Discourse and Literature of the Polish-Ukrainian Boundary of the XX Century» by Oleksiy Sukhomlynov.

Reviewed monograph indicates that Victoria Durkalevych has found her own interpretative approach to literary creations of Ivan Franko, Bruno Schults and Andzhej Ktsiuk. Based on the number of current research in the sphere of literary and cultural studies, sociology the author builds an original interdisciplinary discourse, where the main role is given to such concepts as narrative identity, personal myth and cultural memory. Operation by these categories allows the researcher to identify and analyze common to all works of three authors mechanism of meaning production. 
Monograph consists of an introduction, three chapters and conclusions. In introduction «From the story about the life to the life as story» Victoria Durkalevych justifies the need for the appearance of this type of study, refers to the theoretical basis associated with the research of current problems.

Historical discourse of the analyzed problem arises in sufficient semantic completeness and analytic personal micro-portraits; this segment of research has the general theoretic weight and significance. It is not connected with one or other definitions according to principle: narrative identity, self-narration, autobiographical memory, personal myth, which may be varied to infinity but concerned with certain formulas that convert theory into real effective tool of reception. From the first chapter the multidimensional interpretative approach to literary creation of Ivan Franko, Bruno Shults and Andzhej Ktsiuk has began. In the chapter «Self-narration and therapy: the mythologization of autobiographical discourse in Ivan Franko's creation» the author focuses on the specifics of the emergence and constitution of the individual myth in several Franco's texts. The reconstruction of personal myth is based on the Ivan Franko's understanding of literary communication and model of autobiographical prose. The next chapters of monograph has written in the same way, and they deal with formulating and solving the problem of narrative identity in Bruno Schults and Andzhej Ktsiuk's creation. The great role in the interpretation of personal myth by the author of "Cinnamon Shops» and «Sanatorium Under the Sign of the Hourglass» the philosophy of the word and literary hermeneutics are also played. (the researcher clearly shows this in in chapter «Self-narration and catastrophe: the deconstruction of personal myth in Bruno Schulz's prose») In turn, in the constructing of narrative about «Great Kingdom of Balak» (chapter «Self-narration and responsibility: the semiotization of memory in Andzhej Ktsiuk's dilogy») the great modeling role belongs to the author's reflection and self-reflection which has a form of clear meta-discourse articulation. So, it can be state that reviewed work deepens the problem of personal myth primarily with philosophical positions. It's important that mentioned chapters, which at first sight look like apart, are in holistic harmony.

The book enriches primarily the study about Ivan Franko as a science, shows the creation of Ivan Franko in new interpretative context. The author is quite right that chronotypical analysis (the Drohobych text) has its limit of using and it is necessary to review the effects of the use and deepen by the other methods. It seems that there is the most significant achievement of Victoria Durkalevych and her book in this self-consciousness limit. So, it is a certain step towards understanding the prose works of Ivan Franko, on the way that will really lead us to the truth. 